\title{
Britain in the Age of Walpole
}

Each volume in the 'Problems in Focus' series is designed to make available to students important new work on key historical problems and periods that they encounter in their courses. Each volume is devoted to a central topic or theme, and the most important aspects of this are dealt with by specially commissioned essays from scholars in the relevant field. The editorial Introduction reviews the problem or period as a whole, and each essay provides an assessment of the particular aspect, pointing out the areas of development and controversy, and indicating where conclusions can be drawn or where further work is necessary. An annotated bibliography serves as a guide for further reading. 


\section{PROBLEMS IN FOCUS}

\section{TITLES IN PRINT}

The Mid-Tudor Polity c. 1540-1560

edited by Jennifer Loach and Robert Tittler

Church and Society in England: Henry VIII to James I

edited by Felicity Heal and Rosemary O'Day

The Reign of Elizabeth I

edited by Christopher Haigh

The Early Stuart Church, 1603-1642

edited by Kenneth Fincham

Politics and Culture in Early Stuart England

edited by Kevin Sharpe and Peter Lake

The Origins of the English Civil War

edited by Conrad Russell

Reactions to the English Civil War 1642-1649

edited by John Morrill

Absolutism in the Seventeenth Century

edited by John Miller

Britain after the Glorious Revolution 1689-1714

edited by Geoffrey Holmes

Britain in the Age of Walpole

edited by Jeremy Black

British Politics and Society from Walpole to Pitt 1742-1789

edited by Jeremy Black

Britain and the French Revolution

edited by H. T. Dickinson

Enlightened Absolutism

edited by H. M. Scott

Popular Movements, c. 1830-1850

edited by J. T. Ward

British Imperialism in the Nineteenth Century

edited by C. C. Eldridge

Later Victorian Britain, 1867-1900

edited by T. R. Gourvish and Alan O'Day

The Revolution in Ireland, 1879-1923

edited by D. G. Boyce

Britain Since 1945

edited by T. R. Gourvish and Alan O'Day 


\section{Britain in the Age of Walpole EDITED BY JEREMY BLACK}

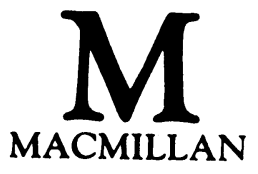


Editorial matter, Introduction and Chapter 6 @ Jeremy Black 1984; Chapter 1 ㅇ Eveline Cruickshanks 1984; Chaper 2 @ H. T. Dickinson 1984; Chapter 3 @ Bruce P. Lenman 1984; Chapter 4 @ David Hayton 1984; Chapter 5 @ Michael Jubb 1984; Chapter 7 @ J. A. Downie 1984; Chapter 8 @ Michael Harris 1984

All rights reserved. No reproduction, copy or transmission of this publication may be made without written permission.

No paragraph of this publication may be reproduced, copied or transmitted save with written permission or in accordance with the provisions of the Copyright, Designs and Patents Act 1988, or under the terms of any licence permitting limited copying issued by the Copyright Licensing Agency, 90 Tottenham Court Road, London W1P 9HE.

Any person who does any unauthorised act in relation to this publication may be liable to criminal prosecution and civil claims for damages.

First published 1984 by

THE MACMILLAN PRESS LTD

Houndmills, Basingstoke, Hampshire RG21 2XS

and London

Companies and representatives

throughout the world

ISBN 978-0-333-36863-3 ISBN 978-1-349-23188-1 (eBook)

DOI 10.1007/978-1-349-23188-1

A catalogue record for this book is available

from the British Library.

Reprinted 1987, 1992, 1994 


\section{Contents}

Preface vii

Introduction: an Age of Political Stability?

JEREM Y BLACK

1 The Political Management of Sir Robert Walpole,

1720-42

EVELINE CRUICKSHANKS

2 Popular Politics in the Age of Walpole

H. T. DICKINSON

3 A Client Society: Scotland between the '15 and the ' 4569 BRUCE P. LENMAN

4 Walpole and Ireland

DAVID HAYTON

5 Economic Policy and Economic Development MICHAEL J UBB

6 Foreign Policy in the Age of Walpole

JEREM Y B LACK

7 Walpole, 'the Poet's Foe'

J. A. DOWNIE

8 Print and Politics in the Age of Walpole MICHAEL HARRIS

List of Abbreviations

Bibliography

Notes and References

Notes on Contributors 


\section{Preface}

EighteENTH-Gentury British history has been noted traditionally for the vigour, not to say acrimony, with which controversies have been conducted. It is therefore a particular pleasure to record that this volume was produced without any disagreement. Differing views are presented, as is only healthy, and the following chapters provide evidence for the very vigorous nature of current historical scholarship for this period. Despite considerable effort, it was unfortunately impossible to fulfil earlier plans for chapters on social and religious developments. I should like to thank the other contributors for their invaluable advice and assistance, and Sarah Mahaffy and Vanessa Peerless of Macmillan for their patient help. Finally, I should like to thank my wife for all her support.

It is an honour to head the list of acknowledgements with the name of Her Majesty Queen Elizabeth II by whose gracious permission the Stuart Papers were consulted. Prince Kinsky, the Duke of Devonshire, the Duke of Richmond, the Marquess of Cholmondeley, the Earl of Egremont, the Earl of Harrowby, Earl Waldegrave, Lady Teresa Agnew and Lady Lucas kindly granted access to their papers.

Thanks are also due to the Huntington Library, the British Academy, the British Council, the German Academic Exchange Scheme, the Institut Francophone de Paris, and the Staff Travel and Research Fund of Durham University. 